\title{
MODELLING INTEGRATED EXTREME HYDROLOGY
}

\author{
FRANCISCO PADILLA ${ }^{1}$, J-HORACIO HERNÁNDEZ ${ }^{2}$, RICARDO JUNCOSA ${ }^{1}$ \& PABLO R.-VELLANDO \\ ${ }^{1}$ ETS de Ingenieros de Caminos, University of A Coruña, Spain, and Wessex Institute of Technology, UK. \\ ${ }^{2}$ Ingeniería Geomática e Hidráulica, University of Guanajuato, Mexico.
}

\begin{abstract}
The present research is concerned with some numerical developments and practical application of a physically based numerical model FreshWaterSheds that incorporates a finite element solution to the steady/transient problems of the joint ground/surface fresh/salt water flows in inland and coastal regulated watersheds. The proposed model considers surface and groundwater interactions to be 2-D horizontally distributed and depth-averaged through a diffusive wave approach. Infiltration rates, overland flows and evapotranspiration processes are considered by diffuse discharge from surface water, unsaturated subsoil and groundwater table. New improvements also allow for the management of surface water flow control through the capacity of diversion on flooding zones of catchment areas, as well as on river beds, spillways and outflow operations of floodgates in weirs and dams of reservoirs. Practical application regards the flooding hazard of Aznalcóllar toxic spillages. This flooding disaster was caused by the sequential ruptures of the dikes of two mining residual reservoirs of a pyrite mine, releasing about $10 \cdot 10^{6} \mathrm{~m}^{3}$ of contaminated wastewater and mining sludge onto the Guadiamar River. The numerical model was adapted to the wastewater and sludge properties of both sudden spillages, as well as to the river bed, the flooded zones and the underneath alluvial aquifer. The model simulation and calibration were made during the date of this hydrological hazard to the likely discharges and dual hydrograph produced by the sudden twofold failure of both reservoirs.

Keywords: extreme hydrology, finite elements, flood routing, integrated surface/subsurface flows, numerical modelling, wastewater.
\end{abstract}

\section{INTRODUCTION}

Nowadays, there is an increasing need for integrated surface and ground water numerical modelling. The philosophy and role of hydrological models in water resources has been widely described $[1,2$.

Recent numerical methodologies were also developed on combined surface and ground-water applications to the whole of the water resources of a particular river basin [3, 4]. MIKE SHE and MIKE BASIN are two examples of numerical and physically based modelling systems developed by DHI [5] for the major flow processes of the hydrological cycle which integrates the Saint-Venant surface equation to a vertical 1-D Richards equation for unsaturated flow and a 3-D finite element solver for saturated flow [6]; Camporese et al. [7], apply a catchment's hydrology model that couples a finite element solver for the Richards equation describing variably saturated porous media, and a finite differences solver for the diffusive wave equation describing surface flow.

Standard features of detailed process-based numerical models for water resources management at the scales of the watershed could include: a large variety of numerical conditions and sub-models for the different hydrological components, water uses and managements. 
These characteristics will not be described in any case here; this research will focus instead on some new features and improvements, summarised below, on an integrated surfacesubsurface flow numerical model FreshWaterSheds that could be also suitable for applications on flooding events of different nature.

In this field, a new methodology of finite element modelling is being recently developed which considers new numerical approaches for the joint surface and ground water regional flows of continental freshwater and coastal saltwater on natural and regulated watersheds $[8,9]$.

The practical application regards the flooding hazard of Aznalcóllar toxic spillages of 1998. This flooding disaster was caused by the sequential ruptures of the dikes of the two mining waste reservoirs of a pyrite mine, releasing about $10 \cdot 10^{6} \mathrm{~m}^{3}$ of contaminated wastewater and sludge onto the Guadiamar River. These two sudden spillages of mining wastewater and sludge were caused by the sudden and sequential twofold failure of both reservoirs, spreading downstream over the river bed and margins, flooded zones and underneath alluvial aquifer, producing the resulting flood routing and the recorded dual hydrograph downstream the Guadiamar River.

\section{MODEL DESCRIPTION}

The FreshWaterSheds model for continental and coastal catchment applications couples subsurface and surface regional hydrology, by a diffusive wave approach, with a joint finite element solver for the saturated porous media flows of fresh and saltwater through an immiscible sharp interface [8].

In this sense, this numerical approach (Fig. 1) was mainly developed in order to be able to analyse anisotropic groundwater behaviour as well as surface water flows at a watershed scale. It can also consider other water components such as the evapotranspiration processes, that is, a diffusive discharge from surface water and soils within the unsaturated zone by a root water uptake sub-model, as well as the overland flow by a rainfall-runoff sub-model based on an exponential method for assessing the infiltration rates [10].

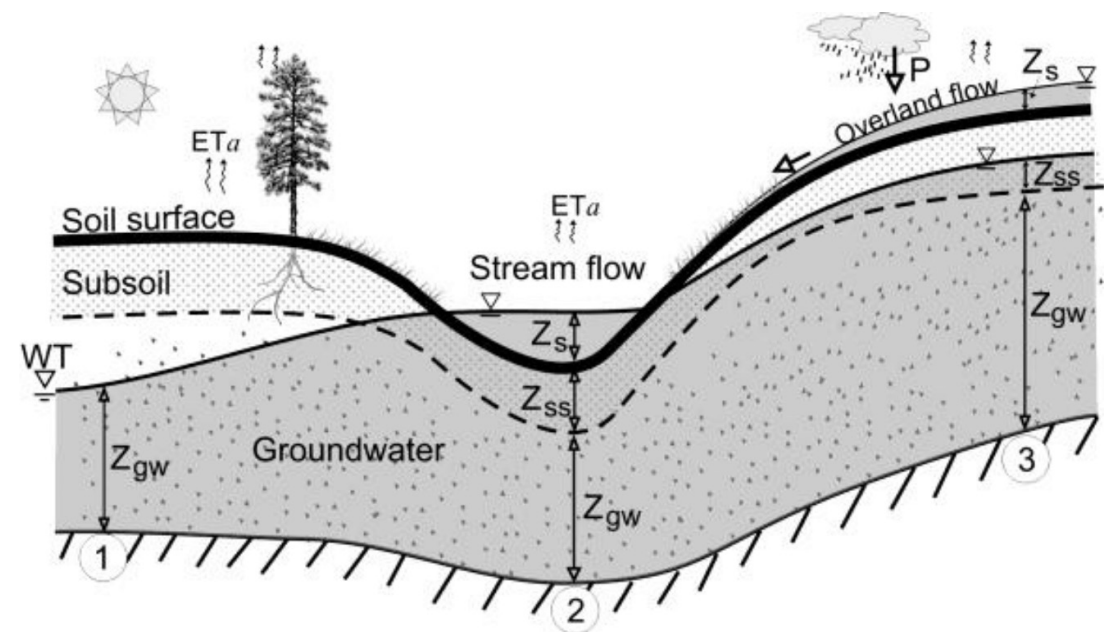

Figure 1: Surface/groundwater flows in FreshWaterSheds interactions. Thicknesses of groundwater $\left(\mathrm{z}_{\mathrm{gw}}\right)$, subsoil $\left(\mathrm{z}_{\mathrm{ss}}\right)$ and stream/overland flow $\left(\mathrm{z}_{\mathrm{s}}\right)$. Water table (WT). Actual evapotranspiration (ETa). [9]. 
The regulation capacities of diversion works may be considered for withdrawing and bypassing certain flow rates of water from a river bed towards other places, by transferring them mainly through impervious channels, pipelines or tunnels. The place where the water is transferred could be located in the same catchment area or in a different one.

FreshWaterSheds, the current tool used in water resources modelling, is a two dimensional finite element model for regional surface and groundwater flows through drainage basins, developed for a temporal implicit (Eulerian) centred (Crank-Nicholson) and spatially centered (Galerkin) numerical approach.

The inputs of freshwater could be exclusively due to rainfall; however, pumping and injection wells of prescribed flow rates have been also implemented, as well as irrigation and artificial recharges, which could be also prescribed inside the considered domain. Therefore, the boundary conditions of the modelled region, at the scale of the watershed, are mainly those of the outflow or discharge conditions. To this respect, prescribed water heads, outflow face and open boundary conditions are commonly used at the discharge zones of the drainage basin [11].

\subsection{Surface-groundwater interactions}

FreshWaterSheds numerical model uses a simplification of the equations governing the free surface flows. In particular, as often happens with other commonly used diffusive wave equations describing surface flow approaches in hydrology, only the classical mass conservation or continuity equation is considered for the present 2-D model.

$$
\frac{d h}{d t}+\nabla \cdot \mathbf{q}=0 ; \text { which leads to: } \frac{d h}{d t}=\nabla \cdot\left(T^{*} \nabla h\right)
$$

In the context of flow diffusion, $h$ represents the hydraulic head, $T *$ is the diffusivity tensor, and $\mathbf{q}$ is the mean horizontal water flow rate per unit length and defined by the Fick's law as a pure-diffusive process.

When a phenomenon is strongly diffusive, it is necessary to take into account the wave nature of diffusive processes to perform accurate predictions, and the hyperbolic diffusion theory is required. Then, the appropriate equation of continuity is derived substituting in system (1) Fick's law by a more general equation due to Cattaneo [12], namely

$$
\begin{aligned}
\frac{d h}{d t}+\nabla \cdot \mathbf{q} & =0 ; \text { where: } \mathbf{q}+D \mathbf{q}=\mathbf{q}+\tau \frac{d \mathbf{q}}{d t}=|\mathbf{q}|=-T^{*} \nabla h \\
& \text { leading to: } \frac{d h}{d t}=\nabla \cdot\left(T^{*} \nabla h\right)+\nabla \cdot\left(\tau \frac{d \mathbf{q}}{d t}\right)
\end{aligned}
$$

This equation defines the hyperbolic diffusion theory, where $\tau$ is the so-called relaxation factor which has dimensions of time.

If we make $\tau / \mathrm{dt}=\mathbf{x}$, and knowing that because of continuity

$$
\nabla \cdot(d \mathbf{q})=\frac{d h}{d t}
$$

The following equations for the hyperbolic diffusion theory can be found:

$$
(1-\mathbf{x}) \frac{d h}{d t}=\nabla \cdot\left(T^{*} \nabla h\right) ; \text { or otherwise: }(1-\mathbf{x}) \nabla \cdot(d \mathbf{q})=-\nabla \cdot|\mathbf{q}|
$$


where, if we gave solution to $\nabla \cdot(d \mathbf{q})$ with respect to the vertical coordinate of the water depth $z_{s}$, and $v_{s}$ taken as the water velocity:

$$
\frac{\partial(d \mathbf{q})}{\partial z_{s}}=\frac{d \mathbf{q}}{z_{s}}=\frac{D \mathbf{q}}{z_{s}^{\mathbf{x}}} \quad ; \quad \frac{\partial\left(d v_{s} \cdot z_{s}\right)}{\partial z_{s}}=d v_{s}+z_{s} \frac{\partial\left(d v_{s}\right)}{\partial z_{s}}=\frac{D v_{s} \cdot z_{s}}{z_{s}^{\mathbf{x}}}=\frac{\mathbf{x} d v_{s} \cdot z_{s}}{z_{s}^{\mathbf{x}}}
$$

which can be rewritten after integration as: (5)

$$
\begin{gathered}
|\mathbf{q}|=-d v_{s}^{0} \cdot(1-\mathbf{x})\left(e^{\mathbf{x} \frac{z_{s}^{1-\mathbf{x}}}{1-\mathbf{x}}}-1\right)=-d v_{s}^{0} \cdot f\left(z_{s}, \mathbf{x}\right) \\
\left(d v_{s} \cdot z_{s}\right)=(d \mathbf{q})=d v_{s}^{0}\left(e^{\mathbf{x}_{s}^{z_{s}^{1-\mathbf{x}}}}-1\right)
\end{gathered}
$$

That gives the mean horizontal flow rates per unit length $\boldsymbol{q}$ as a function of the diffusivity and the hydraulic gradient.

$$
|\mathbf{q}|=-v_{s}^{0} \nabla h \cdot f\left(z_{s}, \mathbf{x}\right)=-K_{s} f\left(z_{s}, \mathbf{x}\right) \cdot \nabla h=-T^{*} \nabla h
$$

Therefore, the $f\left(z_{s}, \mathbf{x}\right)$ function, which has here dimensions of thickness, and the water velocity $v_{s}$, which can be stated through the hydraulic conductivity $K_{s}$ multiplied by the hydraulic gradient, both help to define $|\mathbf{q}|$ as the hydraulic gradient and a function that enhances the hydraulic transmissibility $\left(T^{*}\right)$, here behaving like a diffusive parameter adapted to the free surface flow, that in fact depends on the surface water depth $z_{s}$ and can be adjusted numerically only through the $\mathbf{x}$ parameter.

In order to take into account the diversion capacity of a flooding event or a weir built on a river bed, the following equation has been implemented, defining the velocity of diversion $V$, in terms of the flow rate being diverted per unit area of flooded surface.

$$
V(m / s)=\frac{z_{s}(m) \cdot V_{0}}{10(m)}
$$

where $z_{s}$ is the headwater depth of the overland flow (in meters) or amount of energy available to convey water through diversion, and $V_{0}$ is a parameter that defines a particular velocity of the surface water diversion (in terms of flow rate, that is, diverted volume per unit time and area of flooded surface).

Triangular elements of three nodes are used for the analytic integration of the corresponding numerical formulation for steady and transient conditions. The preconditioned iterative algorithm GMRES [13] provides the solution to the system of equations by means of a reduction in the computer memory requirements and allowing for a simple processing of the numerical mesh.

\section{MODEL APPLICATION}

A large toxic spill occurred in Los Frailes (Aznalcóllar) last April 25 1998, following the rupture of two large tailings reservoirs containing the effluents of a copper and zinc mine that produces pyritic waste rock. Afterwards, it was reported that the failure was caused by a landslide in the base of the joint earth dike of the two mining residual reservoirs, releasing about $10 \cdot 10^{6} \mathrm{~m}^{3}$ of contaminated wastewater and mining sludge onto the Guadiamar River, near Sevilla city (South of Spain) (Fig. 2). 


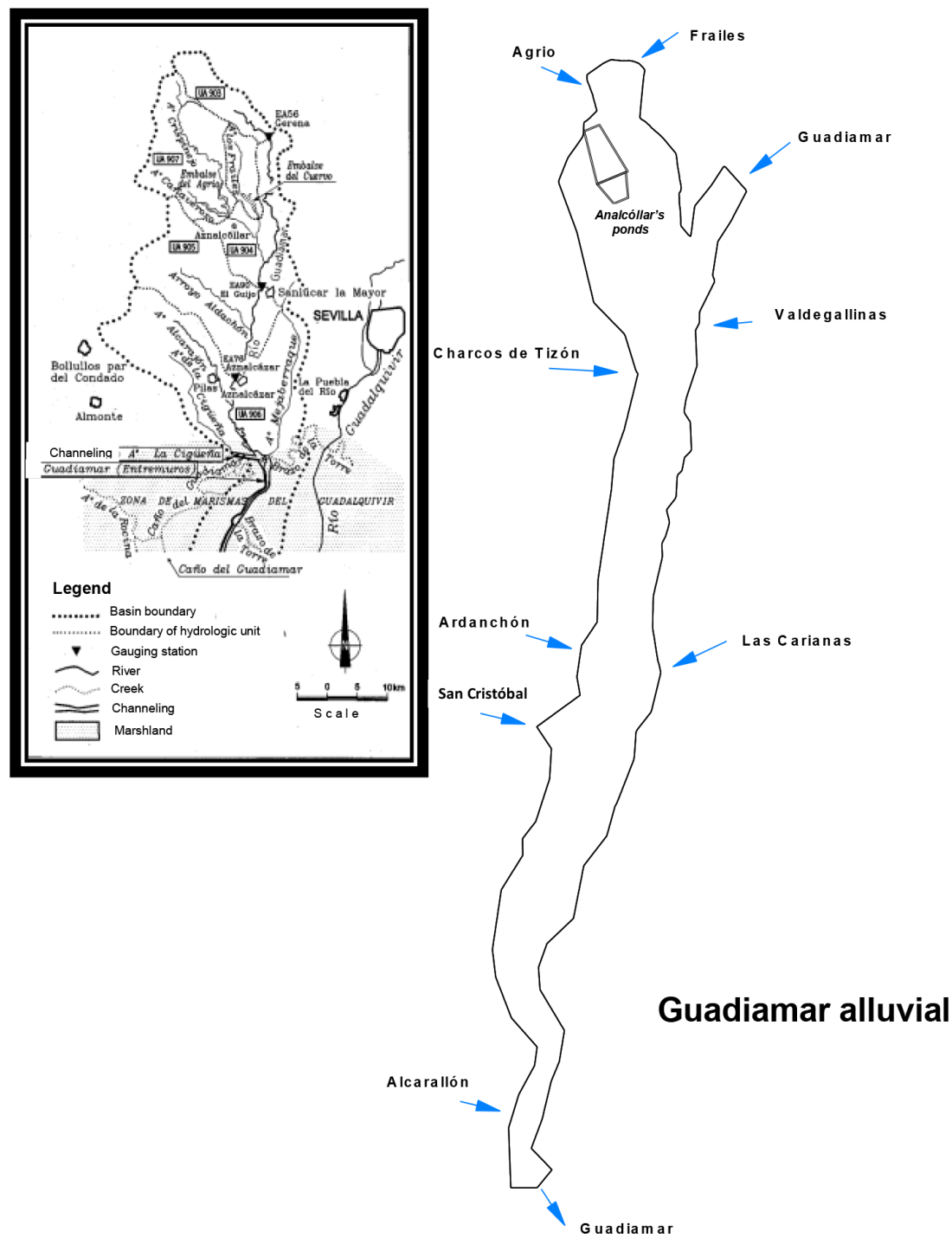

Figure 2: Localisation of Aznalcóllar's ponds, Guadiamar basin and main alluvial, Sevilla (South of Spain).

The aim of this research is to perform the transient simulation of these flooding events by the simultaneous flows of surface and ground waters through the alluvial aquifer and the rivers Agrio and Guadiamar during the $24 \mathrm{~h}$ of April 25 1998, the day that lasted the main flooding events caused by the sequential ruptures occurred at the Aznalcóllar wastewater ponds.

The location of the discharges that caused the flooding events should be restricted to the area where the main breakage occurred. The site after rupture responds to an opening in the earth dam of about $45 \mathrm{~m}$ wide and $23 \mathrm{~m}$ high. This, though relatively small to the scale of the discrete model, can be seen in Fig. 3. 


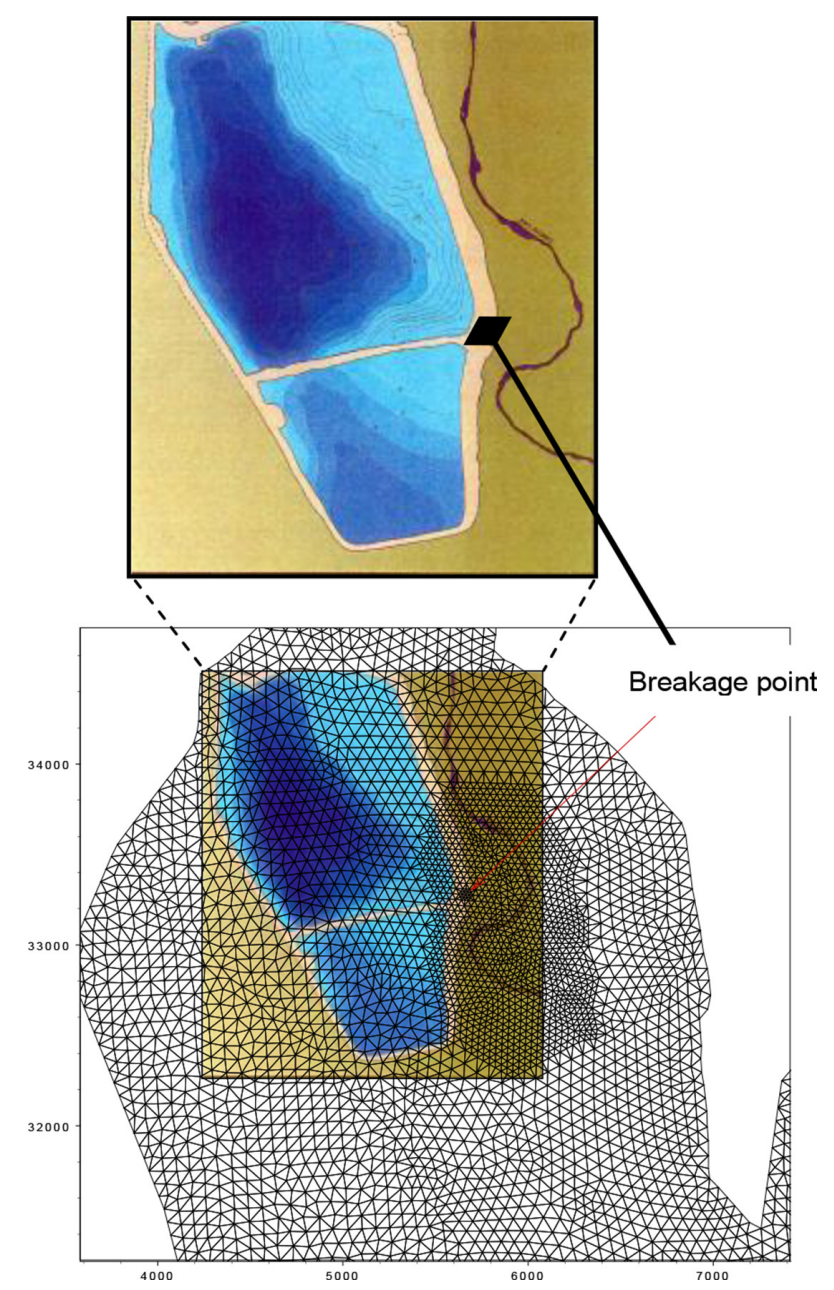

Figure 3: Discrete numerical model in the vicinity of Aznalcóllar's mining waste reservoirs.

The apparently first breakage of the ground retaining wall began in the early hours of Saturday April 25, 1998, between 0:30 am and 1:00 am [14]. The origin of the spillage was then in the area of intersection of the main wall with the dike that divides the reservoir into two ponds: the pyroclastic deposit or pond located to the north, larger, and the pond of pyrites located to the south. Essentially, the general breakage caused firstly the spillage of acidic water from the pyroclastic pond, and secondly and afterwards, a significant amount of sludge mostly from the pyrites pond [15]. This fact was recorded in the limnigraph of the gauging station EA-90 El Guijo. There are two main peaks appreciated in the limnigraph, which are interpreted as corresponding to the two phases in the breaking, one of them mainly from the pyroclastic pond and the other from the pyrites pond [16]; Fig. 4).

The simulation conditions of the model have also been adapted in order to take into account the lateral contributions of surface and groundwater coming from upstream and outside from the watershed that drains its freshwaters throughout the alluvial discrete model of the Agrio and Guadiamar rivers. As a result of the hydrological analysis, lateral contributions are dis- 


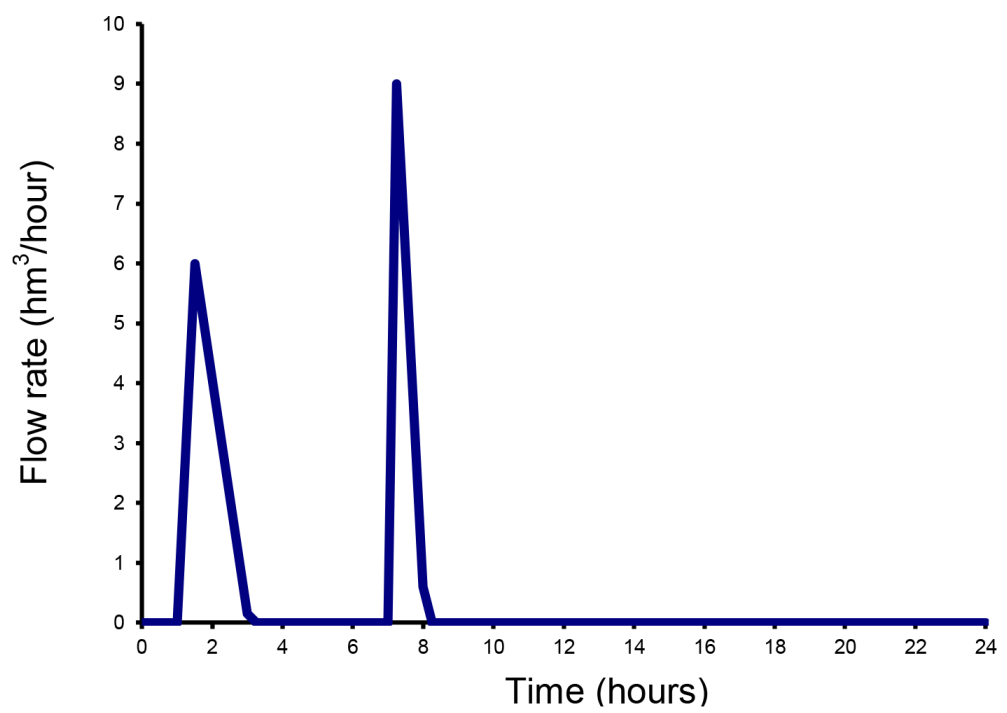

Figure 4: Observed and simulated limnigraphs at the El Guijo's gauging station the 25 April, 1998.

tributed between surface and groundwater. All considered, the dry year adds up to $100 \cdot 10^{6}$ $\mathrm{m}^{3} /$ year [17]. The distribution of these water contributions were also made up by sub-basins. As a result of all the above hydrological conditions, the simulation is performed for a known averaged water contribution of a dry year that is characteristic of the alluvial of the rivers Agrio and Guadiamar.

As follows up from the analysis of the existing data on the state of the two reservoirs of mining waste, before and after the accidental release (Fig. 3), and the recorded limnigraph of the events in the El Guijo's gauging station (Fig. 4), it seems quite clear that the accidental spillage occurred in two phases.

On the other hand, the volumes and types of materials involved in the breakages of both reservoirs of pyroclasts and pyrites are relatively well known, essentially water, sludge and

Table 1: Likely distribution of released water, sludge and soils in the two spillages produced by the breakage of the Aznalcóllar's waste reservoirs.

\begin{tabular}{|c|c|c|c|c|c|}
\hline $\begin{array}{l}\text { Volumes } \\
\left(\mathrm{hm}^{3}\right)\end{array}$ & $\begin{array}{l}\text { Pyroclastic } \\
\text { pond }\end{array}$ & $\begin{array}{l}\text { Pond of } \\
\text { pyrites }\end{array}$ & Dike & $\begin{array}{l}\text { Total } \\
\text { materials }\end{array}$ & Total \\
\hline 1st Spillage & 6.0 water & & & 6.0 water & 6.0 \\
\hline 2nd Spillage & $\begin{array}{l}1.58 \text { water } \\
0.84 \text { sludge }\end{array}$ & $\begin{array}{l}0.85 \text { water } \\
1.05 \text { sludge }\end{array}$ & 0.18 soils & $\begin{array}{l}2.43 \text { water } \\
1.89 \text { sludge } \\
0.18 \text { soils }\end{array}$ & 4.5 \\
\hline $\begin{array}{l}\text { Total } \\
\text { materials }\end{array}$ & $\begin{array}{l}7.58 \text { water } \\
0.84 \text { sludge }\end{array}$ & $\begin{array}{l}0.85 \text { water } \\
1.05 \text { sludge }\end{array}$ & 0.18 soils & $\begin{array}{l}8.43 \text { water } \\
1.89 \text { sludge } \\
0.18 \text { soils }\end{array}$ & 10.5 \\
\hline Total & 8.42 & 1.9 & 0.18 & 10.5 & 10.5 \\
\hline
\end{tabular}


mixed materials from the dikes or soils. Table 1 indicates a likely distribution of these materials in the two different discharges caused by the rupture of the main joint dike of both tailing reservoirs of Aznalcóllar.

The knowledge of the floods caused by the accident, as registered in EA-90 El Guijo gauging station (Fig. 4), as well as the hypothesis of the distribution of the volumes of the materials involved in the discharges caused by the breakages of the ponds of pyroclasts and pyrites (Table 1), allow somehow for an approximation of the evolution of the discharges caused by the accident of Aznalcóllar (Fig. 5).

The two discharges have a temporal separation of 6 hours, and reached approximately the discharged volumes, that is, $6 \mathrm{Hm}^{3}$ and $4.5 \mathrm{Hm}^{3}$, respectively. In short, the maximum discharge of the first spillage (greater volume) would have been smaller than the maximum of the second spillage (smaller volume).

\section{RESULTS AND DISCUSSION}

It should first be checked whether the simulated water levels in the vicinity of the gauging station EA-90 El Guijo properly compared with the limnigraph registered after the flooding hazard. Figure 4 provides the comparison between the observed and simulated water depths during the $24 \mathrm{~h}$ of the day of the accident.

The drainage simulated layout and the presented outcomes should, however, be interpreted as indicative and approximate (Fig. 6). An overview of the velocity fields generated by this flooding event can also be locally depicted (Fig. 7).

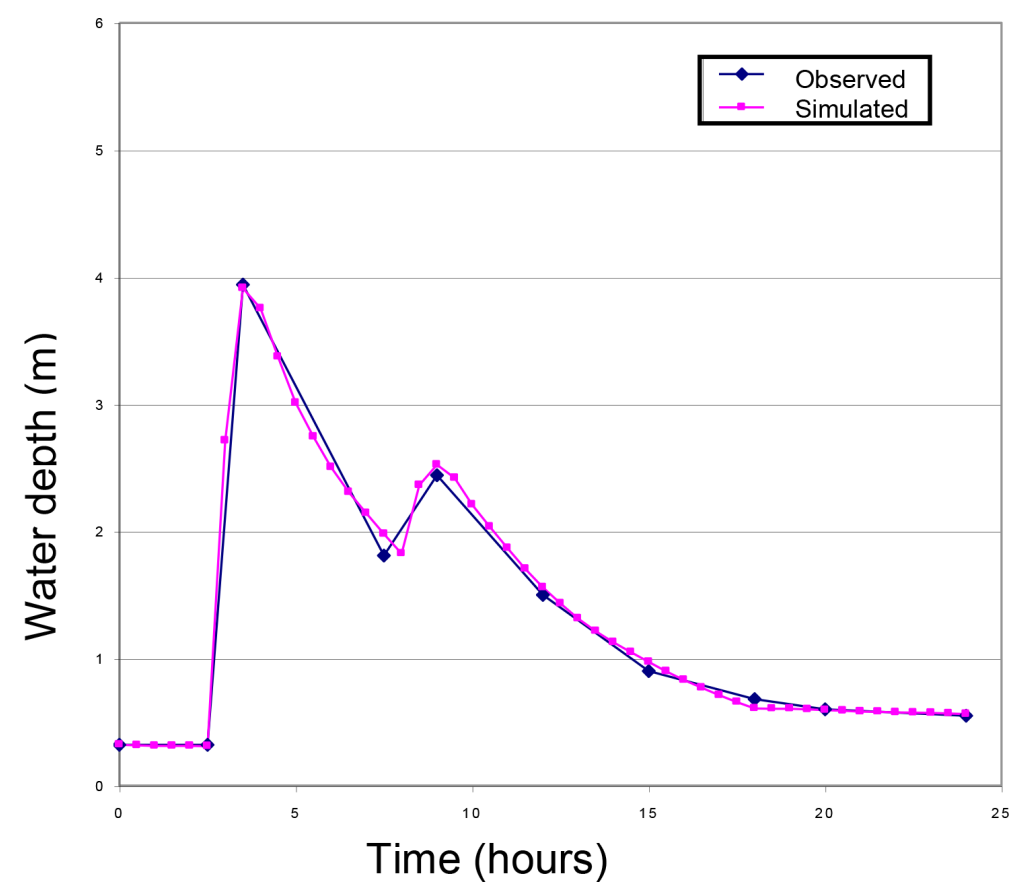

Figure 5: Hypothetical hydrograph of the two discharges produced by the twofold breakage of Aznalcóllar's waste reservoirs. 
Time: 7:30 am

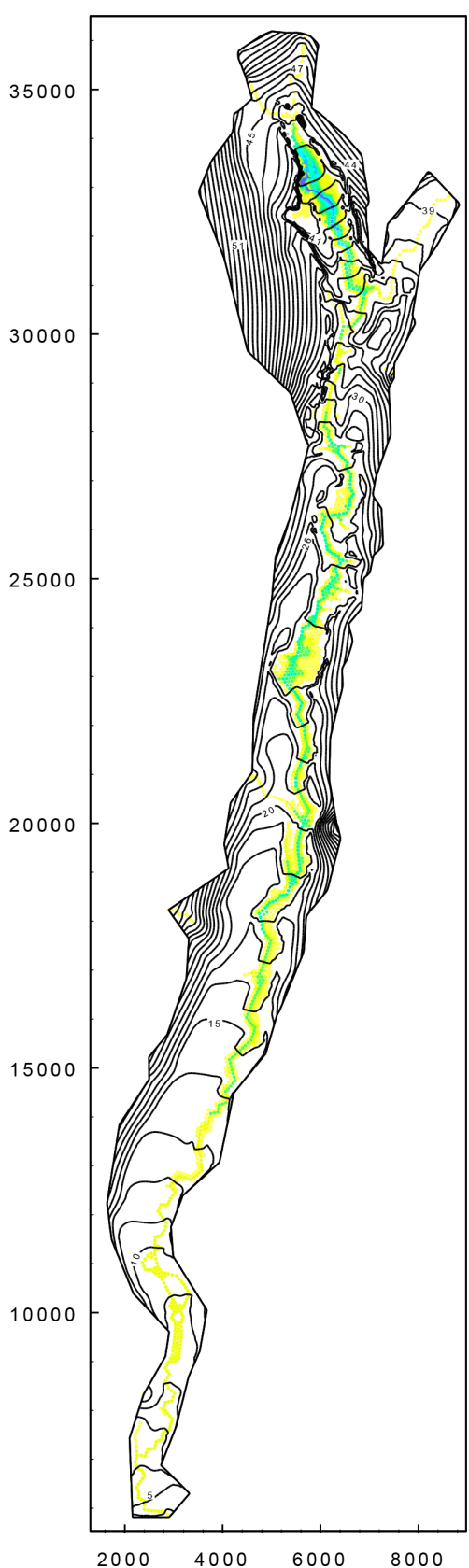

Water depth $(\mathrm{m})$

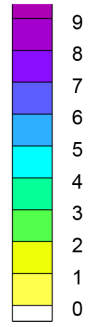

Figure 6: General hydrological layout of groundwater levels and surface water depths in the Guadiamar alluvial at 7:30 am of the 25 April 1998. 
Velocity field of surface water

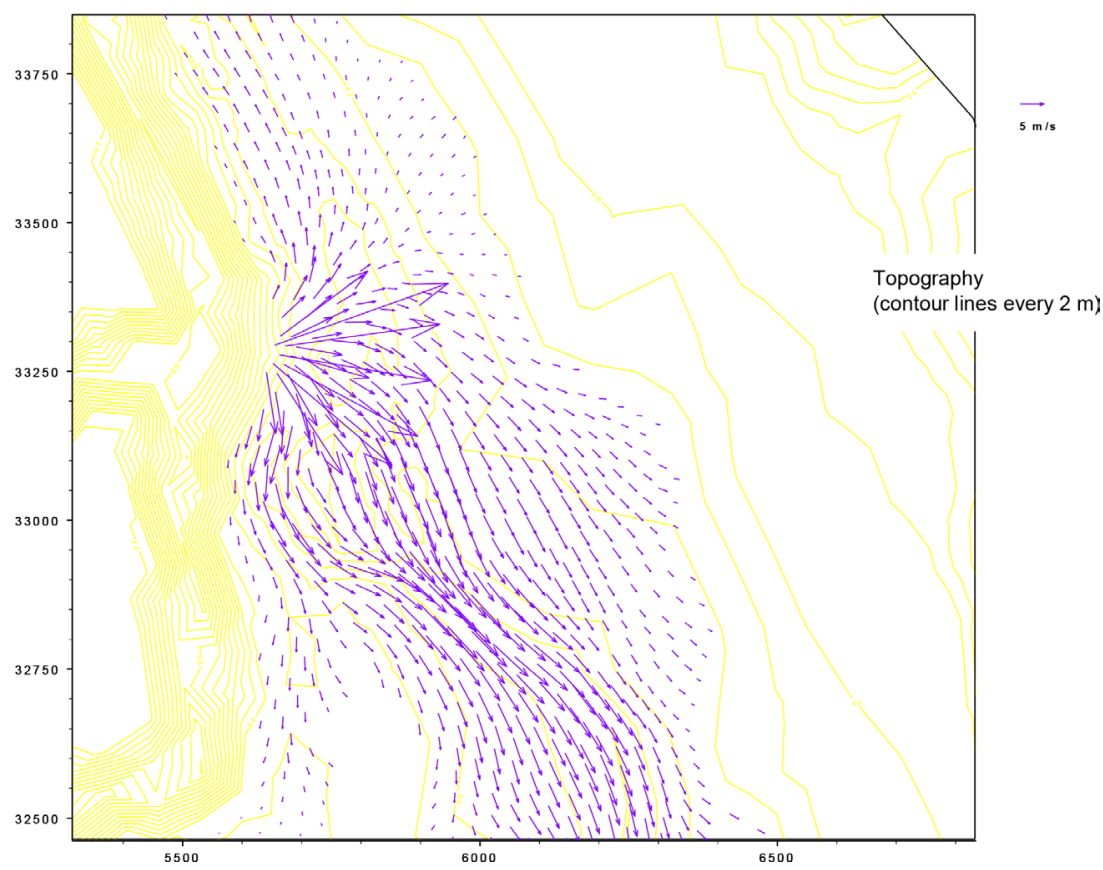

Figure 7: Velocity field of surface water in the vicinity of Aznalcóllar's waste reservoirs at 7:30 am of the 25 April 1998.

Thence this hydrological alternative involving a two phase release of $10.5 \mathrm{hm}^{3}$ of waste water, where there are sequentially two discharges both with the same origin, gives rise to two floods spaced in time and two stages of flooding in certain sectors. Thus the general transient hydrological layout, as well as the different sorts of velocity fields, indicate a strong relationship between groundwater and surface water, as there is a repetition of certain previously flooded areas as well as intermediate periods of temporary drying of a given soil surface, including likely flooding periods of the same previously flooded surfaces.

\section{CONCLUSIONS}

Some new developments have been performed on a process-based integrated numerical model FreshWaterSheds that incorporates a finite element solution to the steady/transient problems of the integrated ground/surface fresh/salt water flows in inland and coastal regulated watersheds. The proposed model considers surface and groundwater interactions to be 2-D horizontally distributed and depth-averaged through a new diffusive wave approach.

This research also aims to improve the acquired knowledge about the characteristics of the alluvial basins of the Agrio and Guadiamar rivers during the period of rupture of the Aznalcóllar mining waste repository. The work has conducted to the analysis of a hydrological alternative that releases a volume of waste water of $10.5 \mathrm{Hm}^{3}$, but nevertheless distributed in a two-phase breakage of a waste water reservoir. 
The simulation conditions are prepared for the times of the reservoir breakages, with an approximate first phase spillage of $6 \mathrm{hm}^{3}$ and a second phase spillage of $4.5 \mathrm{hm}^{3}$ with a $6 \mathrm{~h}$ time in-between. In this sense, a brief calibration of the hydrological parameters of the numerical model were needed in order to better adjust the simulated results to the water depths recorded at the gauging station of El Guijo during the day of the accident.

It is noteworthy that, given the actual knowledge of these flooding events and its very particular hydrological conditions, heretofore the simulated outcomes about the groundwater/ surface water relationships, the velocity fields, the flooding surfaces and the general drainage layout seem in general likely enough. It can also be concluded that the FreshWaterSheds numerical model can provide useful and quite precise results with regard to the integrated behaviours of groundwater and surface waters of different kinds as related to flood routing and flooding events which are significant in the analysis of extreme hydrology in river basins.

\section{ACKNOWLEDGEMENTS}

The work reported in this paper was part of the research conducted on the breakage of Aznalcóllar's dam, funded by DRAGADOS. Our special acknowledgments to José Polimón López and José María Rodríguez Ortiz, directors of the research works.

\section{REFERENCES}

[1] Abbot, M.B. \& Refsgaard, J.C., Distributed Hydrological Modelling. Water Science and Technology Library, Kluver Academic Publishers: Dordrecht, p. 22, 1996. http://dx.doi.org/10.1007/978-94-009-0257-2

[2] Burnash, R.J.C., Ferral, R.L., McGuire, R.A. \& McGuire, R.A., A generalized stream flow simulation system. Conceptual modeling for digital computer. Joint developed by Federal-State River Forecast Center and Nacional Weather Service. Dep. Water Resources (California), 1973.

[3] Ross, M., Said, A., Torut, A., Tara, K. \& Geurink, J., A new discretization scheme for integrated surface and groundwater modelling. In: Integrated Water Resource Management, ed. T.V. Hromadka, American Institute of Hydrology: Las Vegas, Nevada, pp. 143-156, 2005.

[4] Sophocleous, M. \& Perkins, S.P., Methodology and application of combined watershed and ground-water models in Kansas. Journal of Hydrology, 236(3-4), pp. 185-201, 2000. http://dx.doi.org/10.1016/S0022-1694(00)00293-6

[5] DHI. MIKE BASIN. A tool river planning and management. Report, Danish Hydr. Inst., Horsholm, Denmark, 1997.

[6] Graham, D.N. \& Butts, M.B., Flexible, integrated watershed modelling with MIKE SHE. In: Watershed Models, eds. V.P. Singh \& D.K. Frevert, CRC Press: Boca Raton, pp. 245-272, 2005.

[7] Camporese, M., Paniconi, C., Putti, M. \& Orlandini, S., Surface-subsurface flow modeling with path-based runoff routing, boundary condition-based coupling, and assimilation of multisource observation data. Water Resources Research, 46(2), 2010. http://dx.doi.org/10.1029/2008WR007536

[8] Padilla, F., Méndez, A., Fernández, R. \& Vellando, P., Numerical modelling of surfacewater/groundwater flows for freshwater/saltwater hydrology: the case of the alluvial coastal aquifer of the Low Guadalhorce River, Malaga, Spain. Environmental Geology, 55(1), pp. 215-226, 2008.

http://dx.doi.org/10.1007/s00254-007-0977-2 
[9] Padilla, F., Hernández, H., Juncosa, R. \& Vellando, P., A numerical solution for the integrated analysis of water resources management: Application to the Mero River watershed - La Coruña, Spain”. Journal of Water Resource and Protection, 7, pp. 815-829, 2015. http://dx.doi.org/10.4236/jwarp.2015.710066

[10] Hernández, J.H., Padilla, F., Juncosa, R., R-Vellando, P. \& Fernández, A., A numerical solution to integrated water flows: Application to the flooding of an open pit mine at the Barcés River catchment - La Coruña, Spain. Journal of Hydrology, 472-473, pp. 328-339, 2012.

http://dx.doi.org/10.1016/j.jhydrol.2012.09.040

[11] Padilla, F. \& Cruz-Sanjulián, J., Modeling seawater intrusion with open boundary conditions. Ground Water, 35(4), pp. 702-712, 1997.

[12] Cattaneo, M.C., Sur une forme de l'équation de la chaleur limitant le paradoxe d'une propagation instantanée. Comptes Rendus de L'Académie de Sciences: Serie I-Mathematics, 247, pp. 431-433, 1958.

[13] Saad, Y. \& Schultz, M.H., GMRES: A generalized minimal residual algorithm for solving nonsymmetric linear systems. SIAM Journal of on Scientific and Statistical Computing, 7(3), pp. 856-869, 1986.

http://dx.doi.org/10.1137/0907058

[14] Alonso, E. \& Gens, A., Rotura de la balsa de residuos mineros de Aznalcóllar. Universidad Politécnica de Cataluña: Barcelona, 2000 (report).

[15] Mediavilla, C., Arenas, J.M., Carrero, G., Galache, J., Silgado, A. \& Vázquez, E.M., Actuaciones realizadas tras el accidente de Aznalcóllar. Boletín Geológico y Minero. Volumen especial "Las aguas y los suelo tras el accidente de Aznalcóllar", pp. 35-56, 2001.

[16] Mediavilla, C., Borja, F., López Geta, J.A., Martín Machuca, M., Mantecón, R., del Olmo, P., Palancar, M. \& Vives, R., Marco geográfico, geológico e hidrológico regional de la cuenca del Guadiamar. Boletín Geológico y Minero. Volumen especial "Las aguas y los suelo tras el accidente de Aznalcóllar", pp. 13-34, 2001.

[17] Carrera, J., Bernet, O., Bolzicco, J., Castro, A., Jaén, M., Padilla, F., Salvany, J.M., Vázquez-Suñé, E. \& Vázquez, M., Modelación numérica de los acuíferos potencialmente afectados por la rotura de la balsa de Aznalcóllar. Boletín Geológico y Minero. Volumen especial "Las aguas y los suelo tras el accidente de Aznalcóllar", pp. 199-227, 2001. 